\title{
Wind-dependent beluga whale dive behavior in Barrow Canyon, Alaska
}

\author{
K.M. Stafford ${ }^{1}$, J.J. Citta ${ }^{2}$, S.R. Okkonen ${ }^{3}$, and R.S. Suydam ${ }^{4}$ \\ ${ }^{1}$ Applied Physics Laboratory, University of Washington, 1013 NE 40 ${ }^{\text {th }}$ St, Seattle WA 98105 \\ USA; kate2@uw.edu. ${ }^{2}$ Arctic Marine Mammal Program, Alaska Department of Fish and Game, \\ 1300 College Road, Fairbanks, Alaska 99701 USA; john.citta@alaska.gov. ${ }^{3}$ Institute of Marine \\ Science, University of Alaska Fairbanks, Fairbanks, AK 99775 USA; srokkonen@alaska.edu. \\ ${ }^{4}$ North Slope Borough, Department of Wildlife Management, PO Box 69, Barrow, AK, 99723 \\ USA; Robert.Suydam@north-slope.org
}

Corresponding author: Kathleen Stafford (kate2@uw.edu) 


\begin{abstract}
Beluga whales (Delphinapterus leucas) are the most abundant cetacean in the Arctic. The Barrow Canyon region, Alaska, is a hotspot for Pacific Arctic belugas, likely because the oceanographic environment provides reliable foraging opportunities. Fronts are known to promote the concentration of planktonic prey; when Barrow-area winds are weak or from the west, a front associated with the Alaskan Coastal Current (ACC) intensifies. This front is weakened or disrupted when strong easterly winds slow or displace the ACC. To determine if winds influence the diving depth of belugas, we used generalized linear mixed models (GLMM) to examine how the dive behavior of animals instrumented with satellite-linked time-depth recorders varied with wind conditions. When projected along-canyon winds are from the WSW and the front associated with the ACC is enhanced, belugas tend to target shallower depths (10$100 \mathrm{~m}$ ) associated with the front. In contrast, when strong winds from the ENE displaced the ACC, belugas tended to spend more time at depths $>200 \mathrm{~m}$ where the Arctic halocline grades into relatively warmer Atlantic Water (AW). The probability of diving to $>200 \mathrm{~m}$, the number of dives $>200 \mathrm{~m}$, and the amount of time spent below $200 \mathrm{~m}$ were all significantly related to alongcanyon wind stress $(\mathrm{p}<0.01)$. From these results and known relationships between wind stress, currents and frontal structure in Barrow Canyon and the characteristic vertical distribution of Arctic cod, we infer that the probability of belugas targeting different depth regimes is based upon how wind stress affects the relative foraging opportunities between these depth regimes. Belugas are known to target AW throughout the Beaufort Sea; however, this is the first work to show that the probability of targeting the AW layer is related to wind stress.
\end{abstract}

\title{
1 Introduction
}

Beluga whales (Delphinapterus leucas) are the most abundant Arctic-endemic cetacean. Their foraging behavior has been tied to glacial face and subsurface current fronts (Lydersen et al., 2001, Ashford et al. 2013; Stafford et al., 2013). In the Pacific Arctic, there are at least two genetically distinct populations that migrate annually between the Bering Sea into the Chukchi and Beaufort Seas: the Eastern Chukchi and Beaufort Sea stocks (O'Corry-Crowe et al. 1997). Depth of dive behavior for Chukchi belugas has recently been linked to water masses: animals frequently dived to the depths where relatively warm Atlantic Water (AW) is overlain by cold Pacific Winter Water (WW, Citta et al. 2013). Arctic cod (Boreogadus saida), and numerous other fish species, are found at high concentrations at the AW/WW boundary in the Beaufort and Chukchi seas (Crawford et al. 2012, Mecklenburg et al. 2014, Hauser et al. 2015). While Pacific Arctic belugas consume a broad range of prey items throughout the water column (Quakenbush et al. 2015), in the Beaufort Sea, Arctic cod is considered one of their most important prey (Loseto et al. 2009). Hauser et al. (2015) found a significant relationship between the dive depths of Chukchi belugas and the vertical distribution of Arctic cod and specifically targeted 200-300 $m$ depth where highest densities of cod have been found from fishery survey data (Parker-Stetter et al. 2011).

Although Chukchi belugas roam widely throughout the Canada Basin, Beaufort and northern Chukchi Sea (Suydam et al. 2001, Citta et al. 2013, Hauser et al. 2014), the Barrow Canyon region is a core use area for belugas from July through October (Hauser et al. 2014). The dominant circulation feature of the Barrow Canyon region during the open water season is the 
Alaskan Coastal Current (ACC; Fig 1a; Paquette \& Bourke, 1974). During summer and early autumn, the ACC carries relatively warm, fresh $\left(\mathrm{T} \geq 3^{\circ} \mathrm{C}, \mathrm{S} \geq 30\right.$; Gong \& Pickart, 2015) Alaskan Coastal Water (ACW) from the Bering and Chukchi seas northward through Barrow Canyon. Colder, saltier $\left(\mathrm{T}<-1^{\circ} \mathrm{C}, \mathrm{S}>31.5\right.$; Gong \& Pickart, 2015) Winter Water (WW) occurs below and seaward of the warmer ACW. Between these two water masses resides a distinct hydrographic front which, near the mouth of Barrow Canyon, intersects the bottom near the shelfbreak at a depth of about $50 \mathrm{~m}$ (Okkonen et al. 2009). Here and subsequently, we use front in a general sense as referring to a feature or region exhibiting locally enhanced horizontal property gradients. When winds are from the southwestern quadrant, the ACC is intensified and the foot of the associated front can migrate deeper to $\sim 100 \mathrm{~m}$ depth (Fig. 1b). Conversely, winds from the northeastern quadrant act to weaken the ACC and its related frontal structure (Fig. 1c) and, if strong enough, will reverse the current along the eastern flank of Barrow Canyon (Weingartner et al. 1998; Okkonen et al., 2009, Stafford et al., 2013). The WW feeds into the Arctic halocline which grades into the relatively warmer $\left(\mathrm{T}>-1^{\circ} \mathrm{C}, \mathrm{S}>33.6\right.$; Gong and Pickart, 2015) Atlantic Water (AW) layer at around $200-250 \mathrm{~m}$ depth (Fig. 1d).

Stafford et al. (2013) showed that the spatial distribution and inferred feeding behavior of belugas in the vicinity of Barrow Canyon varied in response to wind-driven changes to the circulation and hydrography within the canyon. Crawford et al. (2012) indicated that Arctic cod, a dominant beluga prey species in the Chukchi and Beaufort seas, preferentially utilized warm near-surface waters and the intermediate depth AW layer. Citta et al. (2013) and Hauser et al. (2015) showed belugas making mostly shallow-type and intermediate-type dives in Barrow Canyon, although the Canyon extends to $300 \mathrm{~m}$ (Itoh et al. 2015). Based on those studies, we hypothesized that beluga dive behavior would focus on the hydrographic front associated with the ACC within Barrow Canyon when winds intensified the ACC and focus on the intermediate Atlantic Water layer when winds weakened the ACC and its associated front. To investigate these hypotheses, we examined how beluga dive behavior recorded by satellite-linked time depth recorder (SL-TDR) tags varied in response to changes in wind stress. 

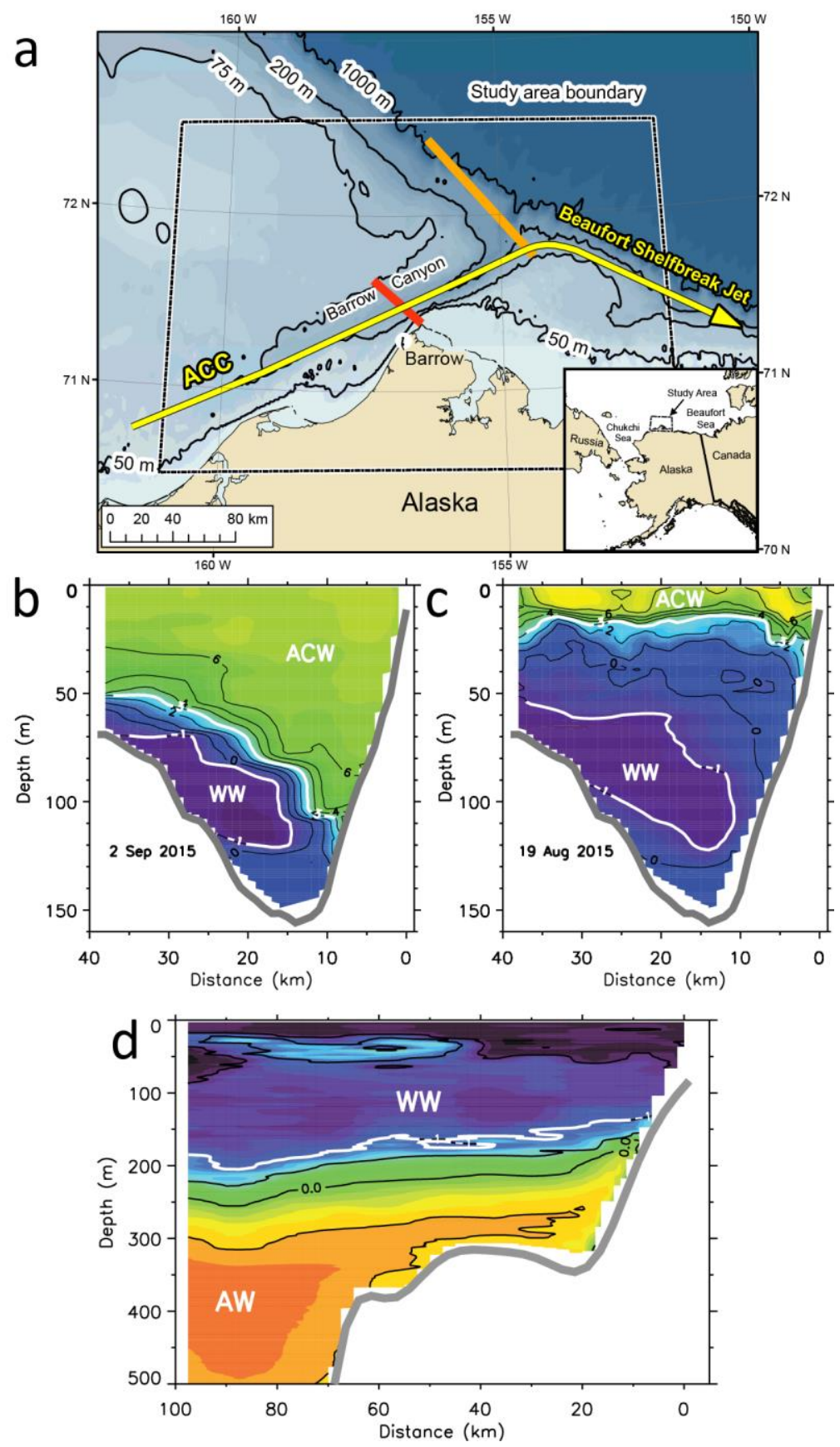

Figure 1. a) Map of the Barrow Canyon study area with schematic of the Alaskan Coastal Current (ACC). Temperature sections across central Barrow Canyon (red transect on 1a) under projected winds from (b) the WSW and (c) the ENE. Point Barrow is on the right side of the plots. d) Late November temperature section across the mouth of Barrow Canyon (orange transect on 1a). White contour lines in panels b-d indicate threshold temperatures delineating principal water masses. ACW - Alaskan Coastal Water; WW - Winter Water; AW - Atlantic Water (note the different depth scales and color palettes for panels $b$ and c compared to panel $d$ ). Bathymetry data are from the International Bathymetric Chart of the Arctic Ocean [IBCAO]; Jakobsson et al., 2012. Oceanographic data are from Okkonen (2013) and Okkonen (pers. comm.). 


\section{Materials and Methods}

\subsection{Study Area}

Several stocks of belugas in the Pacific Arctic region are observed across the Chukchi and Beaufort shelves and offshore over the Arctic Basin but satellite telemetry and aerial survey data indicate higher use of the Beaufort slope and Barrow Canyon (Moore et al. 2000, Suydam et al. 2001, Suydam, 2009) during the open water season; the predominantly ice-free time of year, generally early July through late-October for the Barrow area (Citta et al, 2015; Fig. 6b). Accordingly, we restricted our analyses to the region surrounding Barrow, extending from $161^{\circ}$ $-152^{\circ} \mathrm{W}$ longitude and from $70.5^{\circ}-72.5^{\circ} \mathrm{N}$ latitude (Fig. 1a).

\subsection{Winds}

Stafford et al. (2013) showed that winds projected along the axis of Barrow Canyon were a suitable proxy for ocean currents and hydrographic frontal characteristics in the canyon. Because of the absence of ocean current and hydrographic measurements within the study area that were contemporaneous with the tag data, we make use of these known wind-currenthydrography relationships in our analyses.

NCEP/NCAR (National Centers for Environmental Prediction/National Center for Atmospheric Research) Reanalysis daily surface wind data on a $2.5^{\circ}$ x $2.5^{\circ}$ grid were obtained from the National Oceanic and Atmospheric Administration (Kalnay et al. 1996). As indicated above, the current regime and frontal structure in the vicinity of Barrow Canyon respond to changes in the along-canyon component of the local wind field. Accordingly, daily along-canyon wind stresses, $\tau_{\omega}$, averaged over the study area were estimated from the bulk formula (Hellerman and Rosenstein 1983)

$$
\tau_{\omega}=\rho_{a} C_{d}|W| w
$$

in which $\rho_{a}$ is the air density $\left(1.3 \mathrm{~kg} \mathrm{~m}^{-3}\right), C_{d}$ is the drag coefficient between air and water (0.0014), $W$ is the total wind speed, and $w$ is the vector-averaged wind velocity projected along the axis of Barrow Canyon $\left(65^{\circ} \mathrm{T}\right)$. Here we use wind stress rather than wind speed as it is wind stress that provides the force to change circulation. Positive wind stresses indicate projected winds from the west-southwest (WSW) and negative wind stresses indicate projected winds from the east-northeast (ENE). Subsequent usage of winds from the WSW and winds from the ENE refer to the corresponding projected wind stresses.

\subsection{Location and dive data}

We used data from 22 belugas that were captured and fitted with SL-TDR transmitters between 1998 and 2007 at Point Lay, Alaska. Details of capture and tagging methods are given in Suydam et al. (2001), Suydam (2009), and Citta et al. (2013). The Argos data collection and location system on board NOAA weather satellites was used to obtain locations of animals (Fancy et al. 1988, Rodgers 2001). Locations and associated errors were determined by the Doppler shift between subsequent transmissions during a surfacing when the satellite was overhead (Argos 2013). Service Argos classifies locations as one of six possible classifications based on their accuracy. 
In addition to providing location information, the tags recorded pressure (i.e., depth) every $10 \mathrm{~s}$ and used onboard software to summarize dive information into histograms that covered four 6-hr periods each day. Histograms were collected starting in either late June (1998) or early July (1999, 2001, 2002, and 2007) and were collected until August (1998), September (1999 and 2002), October (2001), or November (2007). 92\% of these dive histograms were acquired in July, August, and September.

For this analysis, we focused on the 'maximum depth' and 'time-at-depth' histograms. Tags recorded the maximum depth of each dive; the maximum depth histograms provide a count of dives within depth bins (i.e., depth category) during each 6-hr period. The time-at-depth histograms record the proportion of time spent within depth bins during each 6-hr period. Threshold values for histogram bins are user-defined and changed by year of deployment (see Citta et al. 2013 for by-year values). This was not a concern for our analysis because we collapsed dive data into simple categories based upon a common threshold shared by all SDR tags (see below).

We statistically estimated a geographic location for each dive histogram. This was necessary because dive data were collected in regular 6-h intervals, but tag locations were calculated by the Argos system opportunistically (i.e., whenever tags can transmit to satellites). How latitude and longitude were assigned to dive histograms is described in detail in Citta et al. (2013). Briefly, a correlated random walk model, implemented in the software package "crawl" (Johnson et al. 2008) was used to estimate beluga location at the beginning of each 6-h period. The state-space formulation required prior knowledge of Argos error distributions for each location class. The model was parameterized using the same Argos location error distributions used by Johnson et al. (2008), based upon the observations of Vincent et al. (2002). As recommended by Johnson et al. (2008), we filtered our location data to remove outliers prior to fitting the state-space model. The filter removed velocities greater than a fixed threshold (McConnell et al. 1992). A threshold of $1.78 \mathrm{~m} / \mathrm{s}$ was chosen after considering a variety of sources (Smith \& Martin 1994, Lydersen et al. 2001, Richard et al. 2001). Only dives occurring within our study area box were retained for subsequent analyses.

\subsection{Dive behavior as a function of wind}

Active acoustic surveys conducted by Crawford et al. (2012) showed that Arctic cod in the Chukchi and Beaufort seas tend to occupy shallow $(<100 \mathrm{~m})$ stratified waters and the relatively warm Atlantic Water layer at intermediate-depth $(>200 \mathrm{~m})$. They largely avoid the colder waters of the intervening halocline. The vertical structure of the cod prey field provided convenient partitioning thresholds of the satellite tag dive histograms for investigation of our wind-dependent dive behavior hypotheses. Although satellite tags were programmed such that the threshold values for depth bins changed by year, there were some common threshold values shared across all years. Common thresholds for dive histograms occurred at 10, 100, and $200 \mathrm{~m}$ (see Citta et al. 2013 for more information on how tags were programmed).

Studies of the Barrow Canyon area and adjacent Beaufort shelfbreak (Pickart et al. 2009; Stafford et al. 2013; Itoh et al. 2015) indicate that ocean currents respond to changes in the wind field at lags ranging from 6 hours to one day. We used generalized linear mixed models (GLMM) to examine how dive behavior varied with wind conditions for dives lagging temporally-interpolated winds at representative lags of 0,12 , and 24 hours. Note that dive data are summarized by the tag during 6-hr periods; as such, we are assigning lags to dive periods, not to individual dives. The GLMM structure was used to fit non-normal error distributions and to 
account for a limited number of belugas that were observed repeatedly. To account for the number of belugas, we coded individual belugas as a random effect, thereby allowing each beluga to have a unique intercept and allowing for population level error. To account for repeated observations, we fit the residuals to a spatial power model which extends the first-order autocorrelation model (AR(1)) to account for unequal intervals between observations (Citta et al. 2013). Models were fit using GLIMMIX procedure in the statistical software SAS (SAS Institute 2011).

We first examined deep diving behavior ( $>200 \mathrm{~m}$ ) and asked if the probability of diving below $200 \mathrm{~m}$ was related to along-canyon wind stress; hereafter, wind stress refers to the alongcanyon component of wind stress. Dive histograms without any dives below $200 \mathrm{~m}$ were coded as ' 0 ' and those with dives deeper than $200 \mathrm{~m}$ were coded as ' 1 '. The probability of diving below $200 \mathrm{~m}$ was then modeled using a logistic link and a binomial error distribution. We then separately modeled the number of dives deeper than $200 \mathrm{~m}$, given that belugas dove deeper than $200 \mathrm{~m}$. After investigating the fit of a variety of link functions and error distributions, we decided to model the number of dives to $>200 \mathrm{~m}$ with an identity link and normal error distribution. Last, using the time-at-depth histogram data, we modeled the amount of time spent below $200 \mathrm{~m}$ as a function of wind stress. The amount of time is recorded as the percentage of the 6-hr interval, so we fit this model using a logistic link and a beta error distribution. We then repeated the same three analyses for dives to $10-100 \mathrm{~m}$, estimating the probability of diving to $10-100 \mathrm{~m}$, the number of dives to $10-100 \mathrm{~m}$ given that belugas dove to $10-100 \mathrm{~m}$, and the amount of time spent within the 10-100 $\mathrm{m}$ depth range.

Model coefficients were estimated by statistical software using restricted maximum likelihood and account for the random effects in the model. Prediction intervals for the models were calculated using "population prediction intervals" as described by Bolker (2008). This method relies on drawing random samples from the estimated sampling distribution of a fitted model. Specifically, we drew 20,000 random sets of coefficients from each fitted model using the vector of means and the variance-covariance matrix. We then calculated the mean using each set of coefficients; the $95 \%$ confidence limits of the mean were the $95 \%$ quantiles of this distribution. 


\section{Results}

A total of 1,554 maximum depth and 1,587 time-at-depth histograms were collected within the study area from 22 belugas (Table 1). Along-canyon wind stresses averaged $-0.035 \mathrm{~Pa}$ over the study area for the ensemble of July-September winds from the five sample years (Fig. 2). Although wind stresses ranged from -0.533 to $0.424 \mathrm{~Pa}$, the majority (92\%) of wind stresses were between -0.2 and $0.2 \mathrm{~Pa}$. Hence when describing the effects of wind stress, we focus on wind stresses between -0.2 and $0.2 \mathrm{~Pa}$; stresses associated with along-canyon wind speeds between $-/+10.5 \mathrm{~m} \mathrm{~s}^{-1}$.

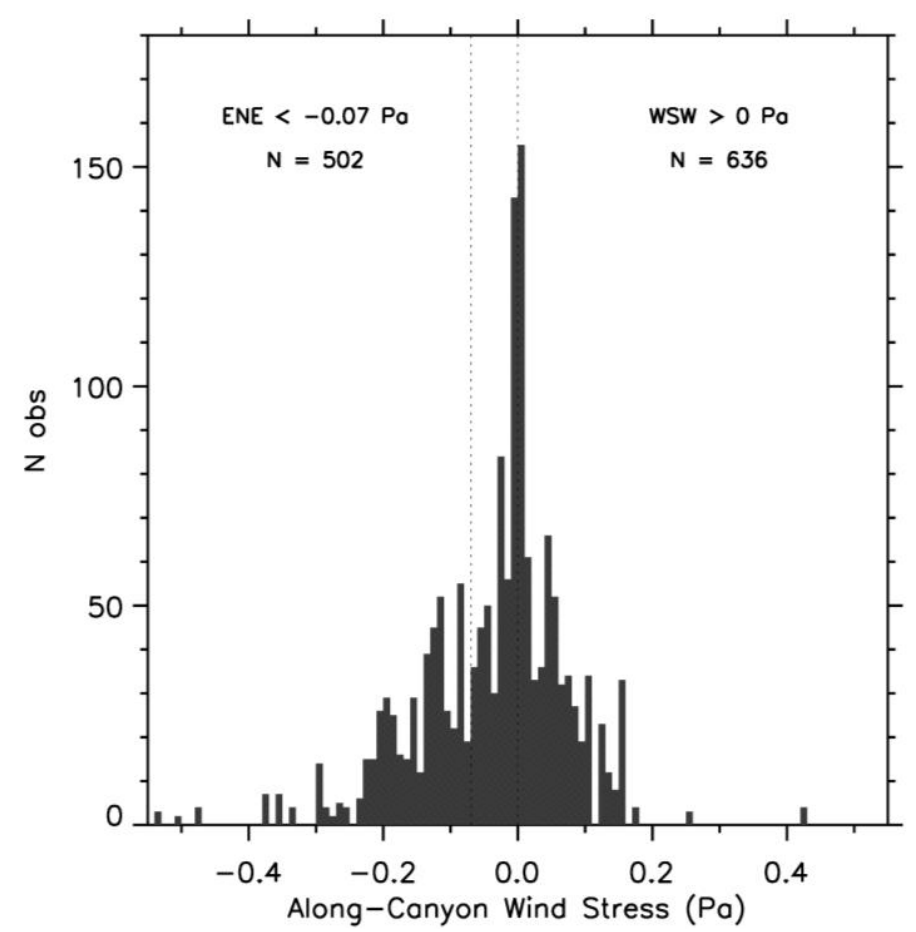

Figure 2. Histogram of along-canyon wind stresses associated with beluga dive records (zero lag). Histogram bin size is $0.01 \mathrm{~Pa}$. WSW wind stresses intensify the ACC and its associated front. ENE wind stresses less than -0.07 Pa displace the ACC, weaken its associated front and reverse the flow along the eastern flank of Barrow Canyon.

\subsection{Diving behavior}

The probability that belugas dove below $200 \mathrm{~m}$ and into the AW layer increased as winds from the ENE strengthened (Fig. 3a). The probability of diving to $>200 \mathrm{~m}$ at least once in a 6-hr interval, the number of dives $>200 \mathrm{~m}$ given that belugas dove to $>200 \mathrm{~m}$ at least once, and the amount of time spent below $200 \mathrm{~m}$ were significantly related to wind stress ( $<<0.01$ for all). The average probability of diving to $>200 \mathrm{~m}$ was $0.54(95 \% \mathrm{CI}=0.41$ to 0.68$)$ when winds from the ENE were strong $\left(10.5 \mathrm{~m} \mathrm{~s}^{-1},-0.2 \mathrm{~Pa}\right.$ ), whereas the probability of diving to $>200 \mathrm{~m}$ decreased to only $0.26(95 \% \mathrm{CI}=0.17$ to 0.39$)$ when winds were from the WSW $\left(10.5 \mathrm{~m} \mathrm{~s}^{-1},+0.2 \mathrm{~Pa}\right)$. A lag of 0 hours fit the data better than lags of 6 or 12 hours. 
Table 1. Total number of maximum depth (MaxDepth) and time-at-depth (TAD) histograms and the number of histograms during which belugas dove to depths $>200 \mathrm{~m}$.

\begin{tabular}{|c|c|c|c|c|c|c|c|c|c|}
\hline \multirow[b]{2}{*}{ Year } & \multirow[b]{2}{*}{ ID } & \multirow[b]{2}{*}{$\begin{array}{l}\text { Whale in } \\
\text { study area }\end{array}$} & \multirow[b]{2}{*}{ Sex } & \multirow[b]{2}{*}{ Age } & \multirow[b]{2}{*}{$\begin{array}{l}\text { Length } \\
(\mathrm{cm})\end{array}$} & \multicolumn{2}{|c|}{$\begin{array}{l}\text { MaxDepth } \\
\text { histograms }\end{array}$} & \multicolumn{2}{|c|}{$\begin{array}{c}\text { TAD } \\
\text { histograms }\end{array}$} \\
\hline & & & & & & $\mathrm{N}$ & $>200 \mathrm{~m}$ & $\mathrm{~N}$ & $>200 \mathrm{~m}$ \\
\hline \multirow[t]{5}{*}{1998} & B98-1 & 28 Jun-3 Jul & Male & Adult & 440 & 20 & 0 & 20 & 0 \\
\hline & B98-2 & $6 \mathrm{Jul}-12 \mathrm{Jul}$ & Male & Adult & 432 & 8 & 0 & 4 & 0 \\
\hline & B98-3 & $6 \mathrm{Jul}-31 \mathrm{Aug}$ & Male & Adult & 398 & 43 & 30 & 44 & 30 \\
\hline & B98-4 & 6 Jul -27 Aug & Male & Adult & 415 & 13 & 5 & 11 & 2 \\
\hline & B98-5 & $6 \mathrm{Jul}-13 \mathrm{Jul}$ & Male & Adult & 414 & 11 & 1 & 9 & 1 \\
\hline \multirow[t]{3}{*}{1999} & B99-2 & 20 Jul-7 Sep & Female & Adult & 266 & 112 & 100 & 128 & 114 \\
\hline & B99-3 & 9 Jul-25 Aug & Male & Adult & 424 & 21 & 10 & 23 & 12 \\
\hline & B99-4 & 8 Jul-14 Jul & Male & Adult & 424 & 11 & 1 & 8 & 0 \\
\hline \multirow[t]{8}{*}{2001} & B01-1 & 10 Jul-9 Aug & Male & Adult & 381 & 14 & 3 & 15 & 1 \\
\hline & B01-2 & 14 Jul-21 Jul & Female & Adult & 359 & 29 & 0 & 29 & 0 \\
\hline & B01-3 & 18 Jul-6 Oct & Female & Immature & 316 & 138 & 73 & 141 & 66 \\
\hline & B01-4 & $21 \mathrm{Jul}-12 \mathrm{Oct}$ & Male & Immature & 324 & 56 & 28 & 77 & 29 \\
\hline & B01-5 & 18 Jul-6 Oct & Female & Immature & 335 & 175 & 82 & 163 & 78 \\
\hline & B01-6 & $21 \mathrm{Jul}-7$ Oct & Male & Adult & 340 & 171 & 60 & 175 & 49 \\
\hline & В01-7 & $18 \mathrm{Jul}-22 \mathrm{Jul}$ & Male & Immature & 320 & 20 & 9 & 19 & 5 \\
\hline & B01-8 & 20 Jul-12 Aug & Male & Immature & 373 & 55 & 19 & 58 & 17 \\
\hline \multirow[t]{3}{*}{2002} & B02-1 & 21 Aug-6 Sep & Female & Immature & 320 & 49 & 35 & 50 & 34 \\
\hline & B02-2 & 25 Jul-7 Sep & Male & Immature & 276 & 76 & 30 & 74 & 28 \\
\hline & B02-4 & 13 Aug-10 Sep & Male & Immature & 267 & 47 & 17 & 39 & 13 \\
\hline \multirow[t]{3}{*}{2007} & В07-1 & 8 Jul-4 Nov & Male & Adult & 430 & 141 & 75 & 156 & 80 \\
\hline & В07-2 & 15 Jul-4 Nov & Female & Adult & 386 & 152 & 65 & 157 & 68 \\
\hline & B07-3 & 8 Jul-13 Nov & Female & Adult & 398 & 192 & 73 & 187 & 78 \\
\hline Totals & & & & & & 1554 & 716 & 1587 & 705 \\
\hline
\end{tabular}

For those 6-hr periods in which belugas made at least one dive $>200 \mathrm{~m}$, belugas made more dives to $>200 \mathrm{~m}$ when winds were from the ENE than when winds were from the WSW (Fig. 3b). On average, belugas dove to $>200 \mathrm{~m} 13.3$ times (95\% CI $=10.9$ to 15.65$)$ under ENE 
winds $(-0.2 \mathrm{~Pa})$ and only 8.6 times $(95 \% \mathrm{CI}=6.1$ to 10.9$)$ under WSW winds $(+0.2 \mathrm{~Pa})$. Again, a lag of 0 hours fit the data better than lags of 6 or 12 hours.

Belugas also spent more time at depths $>200 \mathrm{~m}$ when winds were from the ENE than when winds were from the WSW (Fig. 3c). A 12-hr time lag fit the data better than no lag or a 24-hr lag. With winds from the ENE (-0.2 Pa), whales spent $17.5 \%$ (63 min) of the 6-hr interval (95\% CI $=13.8$ to 21.7 ) below $200 \mathrm{~m}$. With strong winds from the WSW (+0.2 Pa), they only spent an average of $9.2 \%$ (33 $\mathrm{min})$ of the $6-\mathrm{hr}$ interval $(95 \% \mathrm{CI}=7.2$ to 11.7$)$ at $>200 \mathrm{~m}$.

The probability that belugas dove to $10-100 \mathrm{~m}$ at least once did not vary significantly with changes in wind stress (Fig. 3d, $p=0.45$ ). However, given that belugas dove to $10-100 \mathrm{~m}$ at least once during a 6-hr interval, the number of dives was significantly related to wind stress $(p=0.02)$. Belugas made more dives to $10-100 \mathrm{~m}$ when winds were from the WSW than when winds were from the ENE (Fig. 3e). As above, a 12-hr time lag fit the data better than no lag or a 24-hr lag. On average, belugas dove $10-100 \mathrm{~m} 22.0$ times (95\% CI $=18.4$ to 25.7) under WSW winds $(+0.2 \mathrm{~Pa})$ and only 18.0 times $(95 \% \mathrm{CI}=14.3$ to 21.6$)$ under ENE winds $(-0.2 \mathrm{~Pa})$. Belugas did not spend significantly more time at 10-100 $\mathrm{m}$ when winds were from the WSW than when winds were from the ENE (Fig. 3f; $p=0.18$ ).

\subsection{Dive locations}

In addition to tagged belugas demonstrating a relationship between dive depths and wind stress, beluga dive locations also exhibit a spatial relationship to wind stress. Stafford et al. (2013) identified two circulation modes in Barrow Canyon: when winds were from the WSW ( $\tau>0.0 \mathrm{~Pa}$ ), the northeastward-flowing ACC was intensified. When winds from the ENE were sufficiently strong $\left(\tau<-0.07 \mathrm{~Pa}, 6.4 \mathrm{~m} \mathrm{~s}^{-1}\right)$, the ACC was displaced and flow reversed to the southwest along the eastern flank of Barrow Canyon. We used these wind regimes to parse the beluga dive locations associated with each dive depth stratum.

Under winds from the WSW, most dives to $>200 \mathrm{~m}$ cluster in the outer NE portion of Barrow Canyon where the bottom depth exceeds $200 \mathrm{~m}$ with a few dives occurring along the slope east of the canyon mouth (Fig. 4a). Under strong winds from the ENE, most dives to the Atlantic Water layer also occur in the outer portion of Barrow Canyon, but the number of dives occurring east of the canyon mouth along the shelf break is about twice the number occurring under WSW wind conditions (Fig. 4b). Shallower dives between 10-100 m during winds from the WSW are primarily distributed along the axis of Barrow Canyon with the greatest dive density occurring near the head of the canyon (Fig. 4c). Under strong winds from the ENE, the geographical distribution of dives to $10-100 \mathrm{~m}$ is similar to that occurring under WSW winds, but the number of these shallower dives is markedly fewer than occur under winds from the WSW (Fig. 4d). 
a

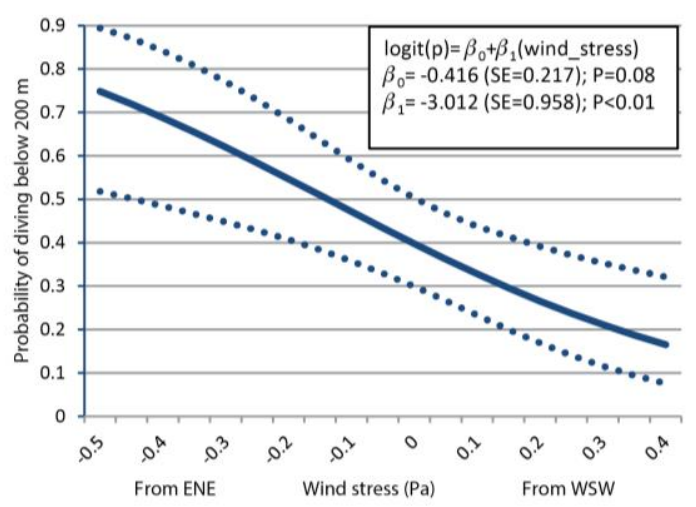

b

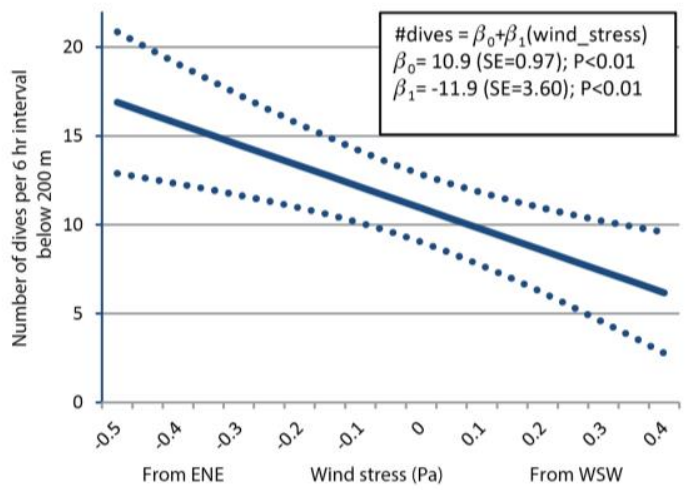

C

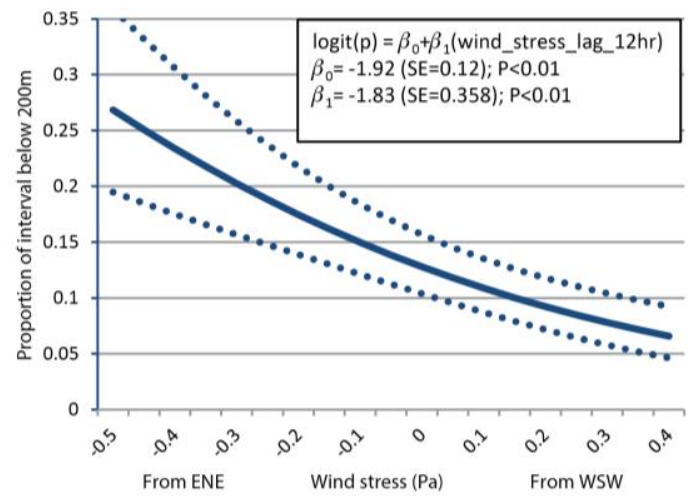

d

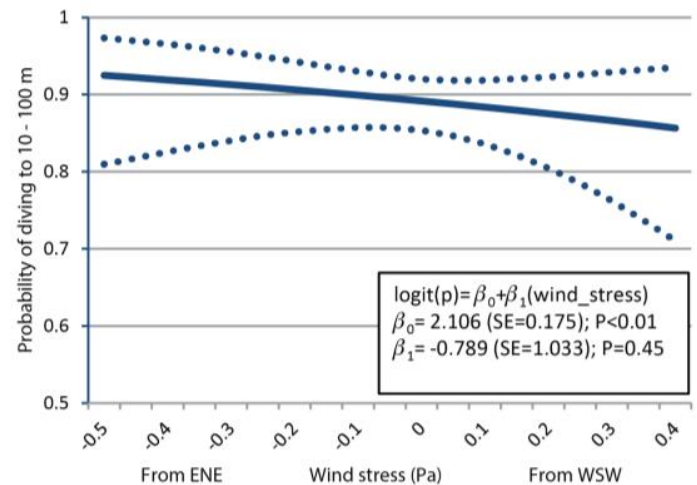

e

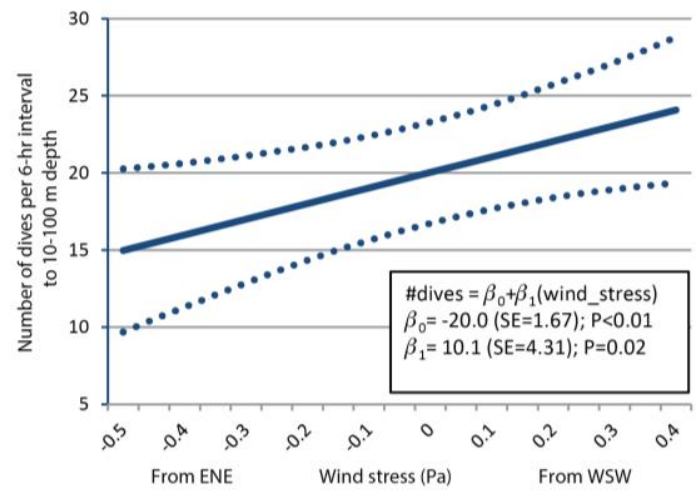

f

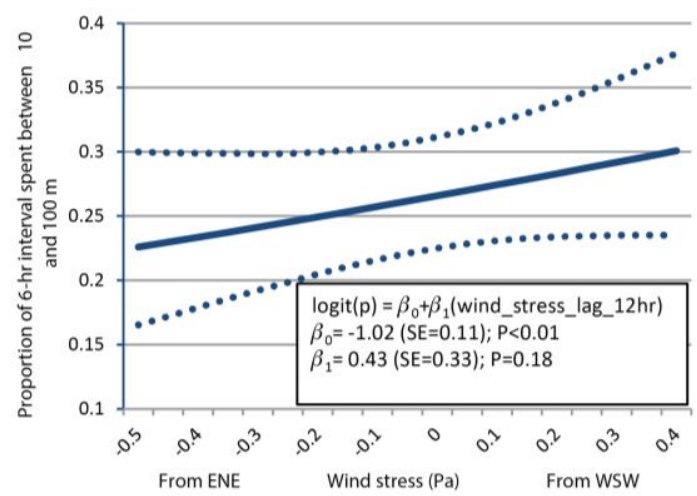

Figure 3. Relationship between wind stress and the (a) probability belugas dive to $>200 \mathrm{~m}$ at least once, (b) the number of dives to $>200 \mathrm{~m}$, conditional on diving to $>200 \mathrm{~m}$, (c) the proportion of the 6-hr interval spent below $200 \mathrm{~m}$, (d) probability belugas dive to $10-100 \mathrm{~m}$ at least once, (e) the number of dives to $10-100 \mathrm{~m}$ conditional on diving to 10-100 m, and (f) the proportion of the 6-hr interval spent 10-100 m. Dotted lines delineate $95 \%$ confidence intervals. 

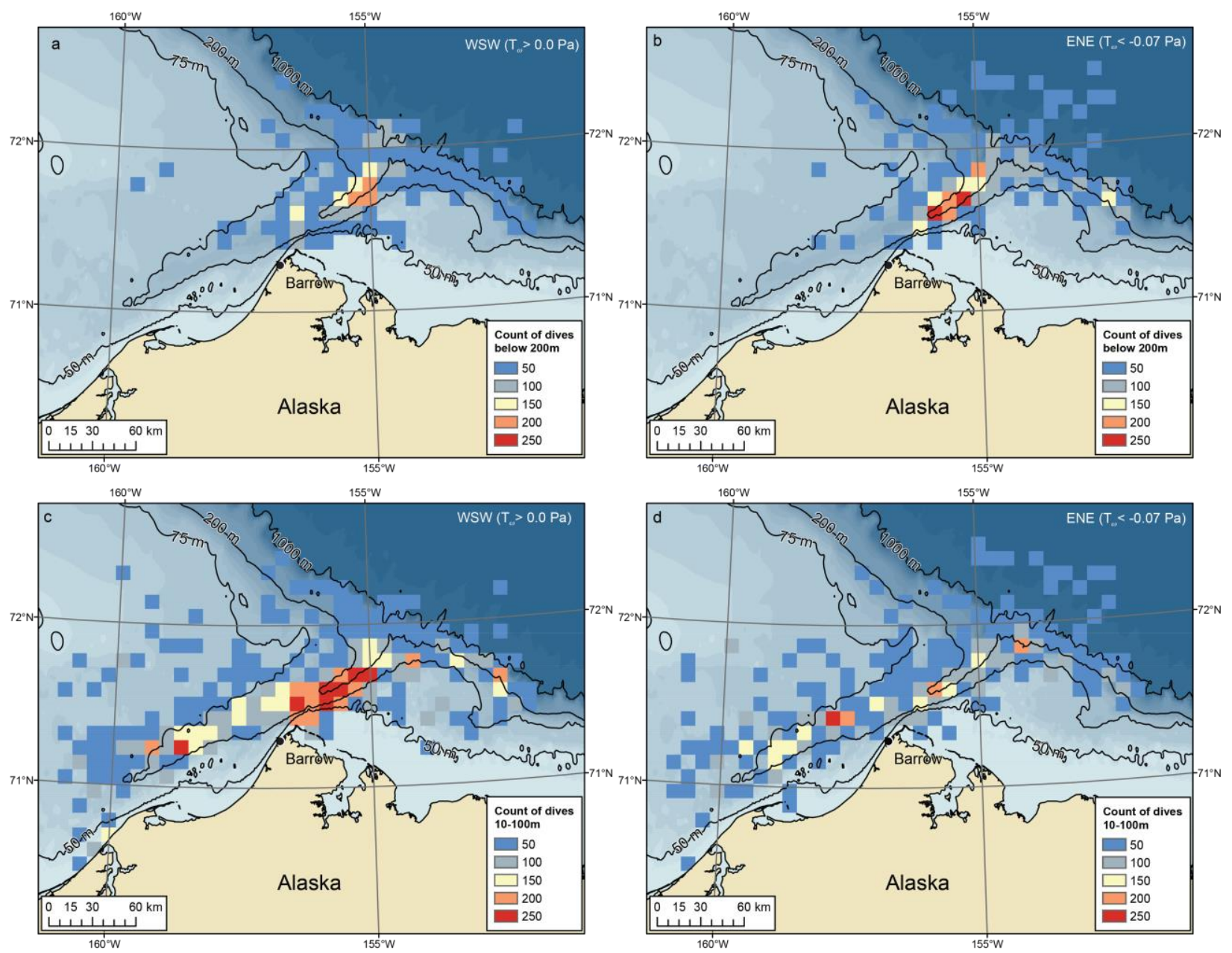

Figure 4. The number of beluga dives to depths (a) $>200 \mathrm{~m}$ for the WSW wind regime, (b) >200 $\mathrm{m}$ for the the ENE wind regime, (c) 10-100 $\mathrm{m}$ for the WSW wind regime, and (d) 10-100 $\mathrm{m}$ for the ENE wind regime. Bathymetry data are from the International Bathymetric Chart of the Arctic Ocean [IBCAO]; Jakobsson et al., 2012.

\section{Discussion}

Fronts are common features of the marine environment. They manifest themselves as regions of enhanced horizontal property gradients (e.g. temperature, salinity, current velocity, nutrient, optical). Their ecological importance arises from associated convergent currents that promote the aggregation of organisms at multiple trophic levels. Large scale oceanic fronts and eddies serve to geographically concentrate species (Wahl et al. 1989, Alcaraz et al. 2007, Galarza et al. 2009) or as enhanced regions for spawning fish (Nieblas et al. 2014). It has been well documented that marine predators cue on frontal regions as areas with increased primary and secondary production (e.g. Olson \& Backus 1985, Russell et al. 1999, Hoefer 2000, Moore \& Lien 2007, Bost et al. 2009 and references therein). To best comprehend how marine mammals, and in this case belugas, use their three-dimensional environment, it is important to understand subsurface oceanographic features and/or frontal structures (i.e. Baumgartner \& Mate 2003, Friedlaender et al. 2006, Dragon et al. 2010, Baumgartner et al. 2013). 
Owing to the absence of prey, ocean current, and hydrographic measurements within the study area that were contemporaneous with the tag data, we rely on regionally characteristic water column distributions of cod and known wind-current-hydrography relationships in our analyses. Beluga dive behavior in the Barrow Canyon region is likely related to the availability of their prey and can be described as a function of along-canyon wind stress. Belugas increasingly target the AW layer when strong winds are from the ENE. Under these conditions, belugas are more likely to dive to the AW layer (>200m), make more dives to this depth, and spend more time there (Fig. 2). The AW layer is known to aggregate prey such as Arctic cod (Parker-Stetter et al. 2011, Crawford et al. 2012, Mecklenburg et al. 2014) and belugas target this layer throughout the Beaufort Sea (Citta et al. 2014, Hauser et al. 2015). However, this is the first work to show that the probability of targeting the AW layer is wind-dependent.

When along-canyon winds are from the WSW, belugas target shallower depths mostly within Barrow Canyon and characteristically associated with the ACC front (Stafford et al. 2013). Although the probability of diving to 10-100 $\mathrm{m}$ during a 6-hr period did not change as a function of wind stress (Fig. 3a), belugas made more dives to 10-100 $\mathrm{m}$ when winds promoted a strong ACC (Fig. 3b). The data also indicate that belugas may spend more time at 10-100 m during WSW wind conditions, although the relationship was not statistically significant (Fig. 3c). Comparing aerial survey data and wind velocity (proxy for ACC velocity) data, Stafford et al. (2013) found larger groups of belugas in Barrow Canyon when the ACC and its associated front were well-developed. They also found that more beluga vocalizations were detected within Barrow Canyon when the ACC and associated front were well-developed, suggesting that belugas move into Barrow Canyon to target prey aggregated by the strong front associated with a well-developed ACC. Our findings are consistent with those of Stafford et al. (2013) in that we found belugas targeting the 10-100 m depth interval in which an intensified front associated with a strong ACC occurs.

Interestingly, there is not an absolute dichotomy between diving to 10-100 $\mathrm{m}$ and diving to $>200 \mathrm{~m}$. Although belugas dive to $>200 \mathrm{~m}$ less often when strong WSW winds dominate, they still dive to $>200 \mathrm{~m}$ under these conditions. However, the average proportion of time spent below $200 \mathrm{~m}$ increased from $\sim 9.2 \%$ with WSW winds $(+0.2 \mathrm{~Pa})$ to $\sim 17.5 \%$ with ENE winds $(-0.2 \mathrm{~Pa})$. For the most extreme winds observed, the difference was even greater; the average proportion of time spent below $200 \mathrm{~m}$ increased from $\sim 6.6 \%$ with strong WSW winds (+0.4 Pa) to $26.8 .5 \%$ with ENE strong winds (-0.5 Pa).

Although belugas spent more time at depths $>200 \mathrm{~m}$ when winds were from the ENE, they also dove to those depths more often. This raises the question of whether or not belugas spend more time at depth per dive or if they just make more dives of equal duration. We have both time-at-depth and maximum depth histogram data for 501 separate 6-hr intervals where belugas spent at least $1 \%$ of the 6 -hr interval below $200 \mathrm{~m}$. Conceptually, we should be able to divide the amount of time spent below $200 \mathrm{~m}$ by the number of dives to deeper than $200 \mathrm{~m}$ to estimate the average duration of dives. In practice, this is questionable because the maximum depth histograms (i.e., the count of dives in different depth bins) are sensitive to how tags measure pressure and classify the end of a dive. Tags were set to record a dive as ending when a beluga ascended through $4 \mathrm{~m}$, but there can be errors in the tag sensor records. According to the tag manuals, the tags we used could accurately measure depth to \pm 2 meters, but it is possible that the error was greater and that multiple dives were sometimes counted as a single dive of anomalously long duration. This could greatly bias the average duration of dives and time at depth per dive. There were 16 records where the average duration was greater than 30 min (32.4 
- $111.6 \mathrm{~min}$ ). Removing these 16 records, we find that the average amount of time spent below $200 \mathrm{~m}$ on each dive was $\sim 5.4 \mathrm{~min}(\mathrm{SD}=4.5)$ when the $\mathrm{ACC}$ was expected to be well-developed (i.e., weak winds or SW or WSW winds; wind stress $>-0.07 \mathrm{~Pa}$ ) and $\sim 5.6 \min (\mathrm{SD}=3.03)$ when wind stress was strong enough to disrupt the ACC (i.e., winds $>6.4 \mathrm{~m} / \mathrm{s}$ from the ENE; wind stress $<-0.07 \mathrm{~Pa}$ ). This difference is not statistically significant and likely not biologically relevant, suggesting that the main reason why belugas spend more time below $200 \mathrm{~m}$ is because they make more dives to that depth, not that they spend more time there on individual dives. Regardless, the relationship between prey density and dive duration is probably not linear. For example, pilot whales (Globicephala macrorhynchus) have been described as "sprinting" on foraging dives, thus spending little time at depth (Aguilar Soto et al. 2008) and bottlenose dolphins (Tursiops truncatus) were found to spend much of their time in surface waters when their preferred prey was on the ocean bottom (Hastie et al. 2006).

Because studies of the Barrow Canyon area and adjacent Beaufort shelfbreak (Pickart et al. 2009; Stafford et al. 2013; Itoh et al. 2015) indicate that ocean currents respond to changes in the wind field at lags ranging from 6 hours to one day, we included lags of 0, 12, and 24 hours in our models. Although the relationship between wind and diving behavior was similar with and without lags, models with no lags generally fit the data better than those with lags. This is not surprising because dive data are summarized by the tag during 6-hr periods; as such, we are assigning lags to dive periods, not to individual dives. Furthermore, the time-stamp for dive periods are associated with the beginning of the period. Hence, each dive period contains dives that are already lagged between 0 and 6 hrs. The true effect of lags is probably also dependent upon the whale's location within Barrow Canyon. As such, the lack of strong lag effects is unsurprising.

Although ascertaining the effect of prey density on dive duration may be elusive, our results strongly suggest that the inferred spatial and temporal variability of prey density affects dive behavior and movements, and reasonably explains different migratory behaviors of belugas in Alaskan waters. Stocks believed to feed extensively on arctic cod, such as the eastern Chukchi and Beaufort Sea stocks, show extensive movements in summer (Richard et al. 2001, Suydam et al. 2001, Suydam 2009). While we expect fish prey to aggregate along frontal features and in the AW layer near Barrow, where Arctic cod are most abundant (Parker-Stetter et al. 2011, Crawford et al. 2012), aggregations are likely patchy and mobile, or are disrupted by feeding belugas, because belugas typically do not remain within the same general location day after day. Rather, whales continually traverse back and forth, transiting the length of Barrow Canyon and along the shelf break, often making large loops that cover hundreds of kilometers (Suydam et al. 2001, Suydam 2009). Those animals may be seeking aggregations of arctic cod or other forage fish, or in the absence of aggregated arctic cod, they may be seeking benthic prey, which are also a substantial component of their diet (Quakenbush et al. 2015).

Such wide-ranging foraging excursions are in contrast to those exhibited by estuarine beluga populations that take advantage of more localized prey resources, such as spawning salmon (Oncorhynchus spp.), smelt (Osmerus spp.), or Eulachon (Thaleichthys spp.). In Alaskan waters, the eastern Bering Sea (Norton Sound), Bristol Bay, and Cook Inlet beluga stocks fit this pattern (Seaman et al. 1982). Belugas in these populations are known to congregate in rivers or near river mouths while fish are spawning and may remain near river mouths as long as fish are present (Frost and Lowry 1990, Goetz et al. 2012, Ashford et al. 2013). While estuarine beluga stocks feed on a variety of prey in addition to spawning fish (Quakenbush et al. 2015), prey are predictably found within much smaller areas, and belugas in these stocks restrict movements to 
individual bays in summer, rather than traversing entire seas, such as do the eastern Chukchi and Beaufort Sea stocks.

\section{Conclusions}

In the Barrow Canyon region, the direction and strength of local winds influence beluga dive behavior. Strong winds from the ENE disrupt the ACC; under these conditions, belugas dive to and spend more time at depths $>200 \mathrm{~m}$, the depth commonly associated with Atlantic water. When the ACC is strong, under weak or WSW winds, belugas made more dives between 10-100 $\mathrm{m}$. This depth range is characteristic of the front that separates the ACC from basin waters. From these results and known relationships between wind stress, currents, and frontal structure in Barrow Canyon and the characteristic vertical distribution of Arctic cod, we infer that belugas target different depth regimes based upon how wind stress affects the relative foraging opportunities between these depth regimes.

A limitation of our study is that we used characteristic vertical distributions of Arctic cod and known relationships between wind conditions and frontal structure in Barrow Canyon to infer relative prey availability from recorded dive behaviors. While the correlation between beluga dive patterns and wind cannot prove prey availability within our categorical depth regimes, we find this relationship between wind and whales to be intriguing. A recent study using some of the same telemetered dive data included information on prey distribution from a region just to the east of Barrow Canyon and found that beluga dive behavior including, and outside of, Barrow Canyon appeared to match the depths at which highest estimated densities of cod were recorded (Parker-Stetter et al. 2011, Hauser et al. 2015). While there was a temporal (beluga and fish data were collected in different years), and sometimes spatial mismatch between the prey surveys and whale dive locations, given the importance of prey density and availability in determining the distribution of beluga populations and the desire to understand how a changing climate may affect the distribution of populations and their prey, this topic warrants further consideration. This will require broader geographic and temporal information on diet of belugas during the open water months, the distribution and density of prey, and how distribution and density are affected by oceanographic conditions. Given that summer easterly winds have increased from 2002 to 2011 resulting in a decrease in ACC transport (Brugler et al. 2014), we might hypothesize that beluga feeding behavior has focused more on the AW layer than the ACC in recent years and that belugas might adapt to climate-driven changes in Arctic wind fields by modifying their foraging behavior. Although we have shown that aspects of beluga dive behavior are significantly related to wind stress, beluga dive behavior is still highly variable. We reiterate the recommendation from Citta et al. (2013) that future tagging and tracking efforts for belugas incorporate oceanographic sensors. This will allow these hydrography/dive depth relationships to be better understood within Barrow Canyon and across the range of eastern Chukchi belugas, and will also provide valuable oceanographic measurements in regions that are otherwise difficult to access (e.g. Lydersen et al. 2002, Charrassin et al. 2004, Laidre et al. 2010).

\section{Acknowledgments}

This project would not have been possible without the help and cooperation of the people and hunters of Point Lay. We especially thank Warren and Dorcus Neakok, Ben and Alice Neakok, Bill and Marie Tracey, Gordon Upicksoun, Thomas Nukapigak, Amos Agnasagga, Julius 
Rexford, and Danny Pikok. Many people assisted in the capture and tagging of belugas and with logistical support and encouragement (see Suydam et al. 2001; Suydam 2009). Funding was provided by the Minerals Management Service, through the Coastal Marine Institute at the University of Alaska. The National Oceanic and Atmospheric Administration provided major funding to the Alaska Beluga Whale Committee through various grants (NOAA grant numbers NA67FX0197, NA9FX0128, NA17FX2593, and NA04NMF4390144). Funding and in-kind support were also provided by the Village of Point Lay; the North Slope Borough's Department of Wildlife Management, Grants Division, and School District; the National Marine Mammal Laboratory of the National Marine Fisheries Service; the Alaska Department of Fish and Game; the Minerals Management Service through the Coastal Marine Institute at the University of Alaska Fairbanks; and the Washington Cooperative Fish and Wildlife Research Unit at the School of Aquatic and Fishery Sciences, University of Washington. The acquisition of hydrographic data was supported by NSF grants PLR-1023446 and PLR-0909193 to S. Okkonen. This research was conducted under Marine Mammal Protection Act permits (Nos. 782-1438 and 782-1719) issued to the National Marine Fisheries Service. Input from Noel Pelland and an anonymous reviewer on an earlier draft greatly improved this manuscript.

\section{References}

Aguilar Soto N, Johnson MP, Madsen PT, Díaz F, Domínguez I, Brito A, Tyack P (2008) Cheetahs of the deep sea: deep foraging sprints in short-finned pilot whales off Tenerife (Canary Islands). J Anim Ecol 77:936-947

Alcaraz M, Calbet A, Estrada M, Marrasé C, Saiz E, Trepat I (2007) Physical control of zooplankton communities in the Catalan Sea. Prog Oceanogr 74:294-312

Ashford JR, Ezer T, Jones CM (2013) River discharge predicts spatial distributions of beluga whales in the Upper Cook Inlet, Alaska, during early summer. Polar Biol 36:1077-1087

Ashjian C (2010) Annual Observations of the Biological and Physical Marine Environment in the Chukchi and Nearshore Beaufort Seas near Barrow, AK. NSF Arctic Data Center. urn:uuid:c85d94c8-8b21-486b-88d5-8bf1fc1d262a.

Bolker BM (2008) Ecological models and data in R. Princeton University Press, Princeton, NJ.

Bost CA, Cotte C, Bailleul F, Cherel Y, Charrassin JB, Guinet C, Ainley DG, Weimerskirch H (2009) The importance of oceanographic fronts to marine birds and mammals of the southern oceans. J Mar Syst 78:363-376

Brugler ET, Pickart RS, Moore G, Roberts S (2014) Seasonal to interannual variability of the Pacific water boundary current in the Beaufort Sea. Prog Oceanogr 127:1-20

Charrassin JB, Park Y-H, Le Maho Y, Bost CA (2004) Fine resolution 3D temperature fields off Kerguelen from instrumented penguins. Deep-Sea Res Pt I 51:2091-2103

Citta JJ, Suydam RS, Quakenbush LT, Frost KJ, and G O'Corry-Crowe. (2013) Dive behavior of eastern Chukchi beluga whales (Delphinapterus leucas), 1998-2008. Arctic 66:389-406.

Crawford R, Vagle S, Carmack E (2012) Water mass and bathymetric characteristics of polar cod habitat along the continental shelf and slope of the Beaufort and Chukchi seas. Polar Biol 35:179-190.

Cunningham RB, Lindenmayer DB (2005) Modeling count data of rare species: some statistical issues. Ecology 86:1135-1142.

Fancy SG, Pank LF, Douglas DC, Curby CH, Garner GW, Amstrup SC, and Regelin WL (1988)

Satellite telemetry: A new tool for wildlife research and management. Resource 
Publication 172. Washington, D.C.: U.S. Department of the Interior, Fish and Wildlife Service.

Galarza JA, Carreras-Carbonell J, Macpherson E, Pascual M, Roques S, Turner GF, Rico C (2009) The influence of oceanographic fronts and early-life-history traits on connectivity among littoral fish species. P Natl A Sci USA 106:1473-1478

Goetz KT, Montgomery RA, Ver Hoef JM, Hobbs RC, Johnson DS (2012) Identifying essential summer habitat of the endangered beluga whale Delphinapterus leucas in Cook Inlet, Alaska. Endanger Species Res 16:135-147

Gong, D and Pickart, RS (2015) Summertime circulation in the eastern Chukchi Sea. Deep-Sea Res Pt II 118:18-31.

Hastie GD, Wilson B, Thompson PM (2006) Diving deep in a foraging hotspot: acoustic insights into bottlenose dolphin dive depths and feeding behaviour. Mar Biol 148:1181-1188

Hauser D, Laidre KL, Suydam RS, Richard PR (2014) Population-specific home ranges and migration timing of Pacific Arctic beluga whales (Delphinapterus leucas). Polar Biol 37: $1171-1183$

Hauser DDW, Laidre KL, Parker-Stetter SL, Horne JK, Suydam RS, Richard PR 2015. Regional diving behavior of Pacific Arctic beluga whales (Delphinapterus leucas) and possible associations with prey. Mar Ecol Prog Ser. 541:245-264. DOI: 10.3354/meps11530.

Hellerman, S., and M. Rosenstein 1983. Normal monthly wind stress over the World Ocean with error estimates. Journal of Physical Oceanography, 13, 1093-1114.

Hoefer CJ (2000) Marine Bird Attraction to Thermal Fronts in the California Current System. The Condor 102:423-427

Itoh M, Pickart RS, Kikuchi T, Fukamachi Y, Ohshima Kay, Simizu D, Arrigo KR, Vagle S, He J, Mathis JT, Nishino S, Nobre C. 2015. Water properties, heat and volume fluxes of Pacific water in Barrow Canyon during summer 2010. Deep-Sea Res. I, 102:43-54.

Jakobsson M, Mayer L, Coakley B, Dowdeswell JA, Forbes S, Fridman B, Hodnesdal H, Noormets R, Pedersen R, Rebesco M, Schenke HW, Zarayskaya Y, Accettella D, Armstrong A, Anderson RM, Bienhoff P, Camerlenghi A, Church I, Edwards M, Gardner JV, Hall JK, Hell B, Hestvik O, Kristoffersen Y, Marcussen C, Mohammad R, Mosher D, Nghiem SV, Pedrosa MT, Travaglini PG, Weatherall P (2012) The International Bathymetric Chart of the Arctic Ocean (IBCAO) Version 3.0. Geophysical Research Letters 39. doi:10.1029/2012GL052219

Johnson DS, London JM, Lea M-A, and Durban JW (2008) Continuous-time correlated random walk model for animal telemetry data. Ecology 89(5):1208-1215.

Kalnay E, Kanamitsu M, Kistler R, Collins W, Deaven D, Gandin L, Iredell M, Saha S, White G, Woollen J, Zhu Y, Leetmaa A, Reynolds R, Chelliah M, Ebisuzaki W, Higgins W, Janowiak J, Mo KC, Ropelewski C, Wang J, Jenne R, Joseph D (1996) The NCEP/NCAR 40-Year Reanalysis Project. Bull. Amer. Meteor. Soc. 77: 437-471.

Laidre KL, Heide-Jørgensen MP, Ermold W, Steele M (2010) Narwhals document continued warming of southern Baffin Bay. J Geophys Res: Oceans (1978-2012) 115(C10049). doi:10.1029/2009JC005820

Loseto LL, Stern GA, Connelly TL, Deibel D, Gemmill T, Prokopowicz A, Fortier L, and Ferguson SH (2009) Summer diet of beluga whales inferred by fatty acid analysis of the eastern Beaufort Sea food web. J Exp Mar Biol Ecol 374:12-18.

Lydersen C, Martin AR, Kovacs KM, and Gjertz I (2001) Summer and autumn movements of white whales (Delphinapterus leucas) in Svalbard, Norway. Mar Ecol Prog Ser 219:265- 
274.

Lydersen C, Nøst OA, Lovell P, McConnell BJ, Gammelsrød T, Hunter C, Fedak MA, Kovacs KM (2002) Salinity and temperature structure of a freezing Arctic fjord-monitored by white whales (Delphinapterus leucas). Geophys Res Lett 29:2119

McConnell, B.J., Chambers, C., and Fedak, M.A. 1992. Foraging ecology of southern elephant seals in relation to the bathymetry and productivity of the Southern Ocean. Antarct Sci 4(4):393-398.

Moore SE, DeMaster DP, Dayton PK (2000) Cetacean Habitat Selection in the Alaskan Arctic during Summer and Autumn. Arctic 53:432-447

Moore SE, Lien R-C (2007) pilot whales follow internal solitary waves in the South China Sea. Mar Mammal Sci 23:193-196

Nieblas A-E, Demarcq H, Drushka K, Sloyan B, Bonhommeau S (2014) Front variability and surface ocean features of the presumed southern bluefin tuna spawning grounds in the tropical southeast Indian Ocean. Deep-Sea Res Pt II 107:64-76

O'Corry-Crowe G., Suydam R., Rosenberg A., Frost K. J., Dizon A., 1997. Phylogeography, population structure and dispersal patterns of the beluga whale Delphinapterus leucas in the western Nearctic revealed by mitochondrial DNA. Molecular Ecology 6, 955-970.

Okkonen SR, Ashjian C, Campbell R, Clarke J, Moore SE, Taylor K (2011) Satellite observations of circulation features associated with a bowhead whale feeding "hotspot" near Barrow, Alaska. Remote Sens Environ 115:2168-2174

Okkonen SR, Ashjian CJ, Campbell RG, Maslowski W, Clement-Kinney J, Potter R (2009) Intrusion of warm Bering/Chukchi waters onto the shelf in the western Beaufort Sea. $\mathrm{J}$ Geophys Res 114:C00A11

Okkonen SR, (2013) Bering, Chukchi, and Beaufort Sea CTD data, Nov-Dec 2011. NSF Arctic Data Center. doi:10.5065/D65T3HGC.

Olson DB, Backus RH (1985) The concentrating of organisms at fronts: A cold-water fish and a warm-core Gulf Stream ring. J Mar Res 43:113-137

Paquette RG, and Bourke RH (1974) Observations on the coastal current of Arctic Alaska. J Mar Res 32:195-207.

Parker-Stetter SL, Horne JK, Weingartner TJ (2011) Distribution of polar cod and age-0 fish in the U.S. Beaufort Sea. Polar Biol 34:1543-1557.

Pickart, R.S., Moore, G.W.K., Torres, D.J., Fratantoni, P.S., Goldsmith, R.A., Yang, J., (2009). Upwelling on the continental slope of the Alaskan Beaufort Sea: storms, ice, and oceanographic response. Journal of Geophysical Research 114, C00A13. doi:10.1029/2208JC005,009.

Quakenbush L, Suydam R, Bryan A, Lowry L, Frost K, and Mahoney B (2015) Diet of beluga whales (Delphinapterus leucas) in Alaska from stomach contents, March-November. Mar Fish Rev 77:70-84.

Richard PR, Martin AR, and Orr JR (2001) Summer and autumn movements of belugas of the eastern Beaufort Sea stock. Arctic 54:223-236.

Rodgers AR (2001) Recent telemetry technology. In: Millspaugh JJ, and Marzluff JM, eds. Radio tracking and animal populations. San Diego, California: Academic Press. 79-121.

Russell R, Harrison N, Hunt GL Jr. (1999) Foraging at a front: hydrography, zooplankton, and avian planktivory in the northern Bering Sea. Mar Ecol Prog Ser 182:77-93

SAS Institute Inc. 2011. SAS OnlineDoc 9.3. Cary, NC, USA. Available online at: https://support.sas.com/documentation/cdl/en/statug/63962/HTML/default/viewer.htm\#titlep age.htm 
Seaman GA, Lowry LF, Frost KJ (1982) Foods of belukha whales (Delphinapterus leucas) in western Alaska. Cetology: 1-19.

Smith,TG, and Martin AR (1994) Distribution and movements of belugas, Delphinapterus leucas, in the Canadian High Arctic. Can J Fish Aquatic Sci 51(7):1653-1663.

Stafford KM, Okkonen SR, and Clarke JT (2013) Correlation of a strong Alaska Coastal Current with the presence of beluga whales Delphinapterus leucas near Barrow, Alaska. Mar Ecol Prog Ser 474:287-297, doi:10.3354/meps10076.

Suydam RS (2009) Age, growth, reproduction, and movements of beluga whales (Delphinapterus leucas) from the eastern Chukchi Sea. PhD dissertation, University of Washington, Seattle, Washington. 152 p.

Suydam RS, Lowry LF, Frost KJ, O’Corry-Crowe GM, and Pikok D, Jr (2001) Satellite tracking of eastern Chukchi Sea beluga whales into the Arctic Ocean. Arctic 54(3):237-243.

Vincent C, McConnell BJ, Ridoux V, and Fedak MA (2002) Assessment of Argos location accuracy from satellite tags deployed on captive gray seals. Mar Mammal Sci 18(1):156166.

Wahl, TR, Ainley DG, Benedict AH, and DeGange AR (1989) Associations between seabirds and water-masses in the northern Pacific Ocean in summer. Biol 103:1-11.

Weingartner TJ, Cavalieri DJ, Aagaard K, Sasaki Y (1998) Circulation, dense water formation, and outflow on the northeast Chukchi shelf. J Geophys Res 103:7647-7661.

doi:10.1029/98JC00374 